DOI 10.31558/2617-0248.2021.6.6

удК 316.45:167/168-057.875(477+478)

\title{
ПОЛІТИКА ЗНАННЯ ПОЛІТОЛОГІЧНИХ СПІЛЬНОТ: «КЛАСИЧНІ» ТЕКСТИ У ХАРКОВІ, СІМФЕРОПОЛІ, ЛЬВОВІ ТА КИШИНЕВІ
}

ORCID ID: https://orcid.org/0000-0003-2933-3186

Осін В. В., к. політ. н., доцент Національного технічного університету «Дніпровська політехніка»

Стаття присвячена виявленню впливу ідеологічних орієнтацій політологів та політологинь студентських спільнот України (Львів, Харків, Сімферополь) і Молдови (Кишинів) у період 2012-2013 рр. на уявлення про класичні тексти політичної науки. Робота є частиною масштабнішого дослідження, яке фіксує стан української політології у 2012-2013рр. і дозволяє краще зрозуміти особливості політичних, соціальних, етнічних, економічних, гендерних та дисциплінарних уявлень студентства напередодні подій Революції гідності. Емпіричним базисом статті $є$ результати опитування студентів та студенток I-V курсів, що навчалися за спеціальністю «Політологія» на бакалаврів, спеціалістів та магістрів у Львівському національному університеті імені Івана Франка, Харківському національному університеті імені В. Н. Каразіна, Таврійському національному університеті імені В. І.Вернадського та Державному університеті Молдови.

Відповіді респондентів дозволяють виділити декілька тенденцій. Зокрема йдеться про низький рівень знайомства із сучасними (західними) політологічними роботами та вплив регіонального контексту та ідеологічних уподобань на наукові інтереси. Важливим також $є$ майже цілковита відсутність інтересу студентів та студенток до вітчизняних текстів та/або авторів. Цілковите ігнорування власних наукових та політичних традицій з боку студентів та студенток робить актуальною (пост)колоніальну інтерпретацію української та молдавської політології. Це означає, що студенти цих країн від самого початку звикають до того, що власне політичне життя та способи його категоризації презентують античні, закордонні та пострадянські вчені, політики та навіть письменники. Саме вони, попри очевидні геополітичні конфлікти інтересів, розповідають, що є справжньою політичною наукою, політикою, політичним режимом, політичним минулим та майбутнім тощо.

У завершальній частині статті зроблено висновок про те, що на студентському рівні українську та молдавську політології можна описати як такі, що перебувають у пошуках власної суб'єктності, виступаючи в ролі самопроголошеної «колонії» західної або російської наукової метрополії». Це ставить на чергу порядку денного потребу стати цікавими для себе і зробити відповідні політичні науки по-справжньому актуальними для власних суспільств, виступивши виробниками оригінального знання, а не ретрансляторами чужого досвіду.

Ключові слова: класичні тексти політичної науки, політико-ідеологічні ідентифікації, регіони України, Молдова, історія політичної науки, постколоніалізм.

Osin V. V. The politics of knowledge of political science communities: "classical" texts in Kharkiv, Simferopol, Lviv and Chisinau

The article is devoted to revealing the influence of ideological orientations of students of political science communities of Ukraine (Lviv, Kharkiv, Simferopol) and Moldova (Chisinau) on the political science' classical texts. This work is part of a larger study that captures the state of Ukrainian political science during 2012-2013 and provides a better understanding of the political, social, ethnic, economic, gender and disciplinary views of students on the eve of the Revolution of Dignity. The empirical basis of this article is a survey of the students enrolled in three types of academic program (bachelor's, specialist's and master's degrees) at four universities: Ivan Franko National University of Lviv, V. N. Karazin Kharkiv National University, V.I.Vernadsky Taurida National University and Moldova State University.

The answers of the respondents allowed revealing several tendencies. In particular, this refers to the low level of their acquaintance with modern (Western) political science works as well as the influence of the regional context and ideological preferences on scientific interests. It is also important that students have almost no interest in domestic texts and / or authors. The complete disregard of the national scientific and political traditions by students makes the postcolonial interpretation of Ukrainian and Moldavian political science relevant. This means that Ukrainian and Moldavian students from the very beginning get used to the fact that their own political life and ways of categorizing it are presented by ancient, foreign and postSoviet (mostly Russian) scientists, politicians and even writers. Despite the obvious geopolitical conflicts of interest it is they who tell / explain what a real political science, politics, political past and future, political regimes are. 
The final part of the article concludes that Ukrainian and Moldovan political science at the student level can be described as the one searching for the subjectivity, acting as a self-proclaimed "colony" of the Western or Russian scientific metropole. This puts on the agenda the following: the need to become interesting to themselves and to make the relevant political sciences truly topical to their own societies, acting as the original knowledge makers rather than repeaters of other people's experience.

Keywords: classical texts of political science, political and ideological identifications, regions of Ukraine, Moldova, history of political science, postcolonialism.

Стаття $є$ продовженням серії розвідок здисциплінарної рефлексії української політичної науки. Актуальність теми визначається розбіжністю між відсутністю, з одного боку, вірогідних даних з (історії) регіонального студентського рівня вітчизняної політології та потенційно зростальним ступенем укоріненості декількох тисяч колишніх та нинішніх бакалаврів, спеціалістів та магістрів до політичного життя держави 3 іншого боку.

Мета роботи - виявити вплив ідеологічних оріснтацій політологів та політологинь студентських спільнот України (Львів, Харків, Сімферополь) і Молдови (Кишинів) у період 2012-2013 рр. на уявлення про класичні тексти політичної науки. Хронологічні межі дослідження роблять його вагомим внеском в історію дисципліни. Ця робота є частиною масштабнішого дослідження, яке фіксує стан української політології у 2012-2013 pp. і дозволяє краще зрозуміти особливості політичних, соціальних, етнічних, економічних, гендерних та дисциплінарних уявлень студентства напередодні Революції гідності. Представлені в статті результати були отримані у межах реалізації українсько-молдавського проєкту (Вадим Осін (керівник), Сергій Шуляк, Анжела Зеленскі) з вивчення політики знання на пострадянському просторі. Грант був виділений Центром перспективних наукових досліджень і освіти в області соціальних і гуманітарних наук (CASE), Корпорацією Карнегі (Нью-Йорк) і Американськими радами з міжнародної освіти (ACTR/ACCELS) в рамках Програми «Соціальні трансформації в Прикордонні (Білорусь, Україна, Молдова)», Вільнюс, Литва).

Аналіз останніх досліджень і публікацій. Одним з найбільш перспективних напрямків дисциплінарної рефлексії є дослідження генези уявлень про класичні тексти політичної науки. Альберт Соміт і Джозеф Таненхауз в одних з перших оглядах стану американської політології встановлення переліку класиків звели до спроби виявити список «безсмертних» [7, с. 64-74; 8, с. 223-224]. Роберт Гудін і Ганс-Дітер Клінгеман перераховують цілий ряд релевантних робіт, класифікуючи їх за різноманітними ознаками [9, c. 54-63]. В останній Оксфордський колективній монографії з політичної науки Роберт Гудін вказує на те, що «канон політичної науки можна обгрунтовано описати з погляду набору “основних книг”, 3 якими будь-який компетентний фахівець повинен мати принаймні коротке знайомство»- попри те, що значна кількість сучасної політичної науки «все більше стає дисципліною, заснованою на статтях» $[1$, с. 16]. Схожі спроби були здійснені Наталі Масуокою, Бернардом Грофманом та Скоттом Фелдом [3], а також Лі Сігельманом [6].

У колективній роботі «Политическая наука в Украине: становление и перспективы» [20] ряд статей присвячені відповідній навчальній літературі, в яких можна було очікувати виявлення списку класичних творів. Проте Анатолій Філатов утримується від цього кроку [24], так само як і Мілана Ніколко [17]. Водночас Володимир Муляр, Вікторія Венгерська і Станіслав Сухачов щодо політологічних підручників і посібників Центрального і Західного регіонів України обмежилися таким коментарем: «Бібліографія, подана після кожного розділу, свідчить про залучення достатньої кількості літератури. Це говорить про відповідний рівень наукового плюралізму» [16, с. 127]. Лише Олена Раздіна виділяє на прикладі відповідних посібників найбільш часто цитовані джерела, монографії та періодичні видання [21, с. 81-82].

Спільними для всіх цих робіт є два моменти: по-перше, більшість спроб визначити «золотий фонд» політології далекі від того, щоб прив'язувати авторів і твори до політичних обставин. Це виглядає непослідовно з огляду на дисциплінарну специфіку, яка передбачає увагу до проявів влади в усьому іiі розмаїтті, що, зокрема, проявляється в розробці Пауло Равекка політики знання в межах політичної науки [4]. Це також непослідовно, зважаючи на плідні результати спроб простежити соціально-політичну обумовленість генези класиків. Так, Тимофій Дмитрієв виявляє стратегії, за допомогою яких Лео Штраус зміг домогтися подвійної легітимації своїх ідей [10], проявляючи при цьому проникливість і прагматичне використання політичного клімату. Інший підхід до аналізу класичних творів представлений у роботах відповідного збірника [13], особливо в деконструкції «Великої трансформації» Карла Поланьї [11]. Другим важливим моментом $\epsilon$ акцент на текстах, що поширені серед професійних (академічних) дослідників. Тим самим фіксується лише статус-кво політичної науки, проте дослідники виявляються нездатними вловити процес (зміни), початок якого - завжди в минулому. Однак будь-які класичні тексти не з'являються з нізвідки, оскільки цьому передує вивчення «в процесі навчання, тобто “в класах"» [22, с. 27]. Але шлях певних авторів від студентської аудиторії до академічних публікацій зазвичай не розглядається, що своєю чергою передбачає: частота посилання на автора в академічних публікаціях корелює з інтенсивністю його вивчення студентами й аспірантами. Я вважаю, що все складніше, демонстрації чого і сприятиме ця робота.

Емпіричним базисом статті є результати опитування студентів та студенток I-V курсів, що навчалися за спеціальністю «Політологія» на бакалаврів, спеціалістів та магістрів у Львівському національному університеті імені Івана Франка (надалі ЛНУ), Харківському національному університеті імені В. Н. Каразіна (надалі ХНУ), 
Таврійському національному університеті імені В. І. Вернадського (надалі ТНУ) та Державному університеті Молдови (надалі ДУМ). Детальний опис методології міститься в колективній монографії [18]. У цій роботі тлумачиться уявлення про класичні тексти студентів та студенток Харкова, Львова, Сімферополя та Кишинева.

Релевантні назви та прізвища з'явились в процесі опитування, коли пропонувалось вказати «перелік текстів, якщо такий існує, обов'язковий для прочитання всіма політологами, незалежно від спеціалізації». 17,1 \% респондентів вказали, що таких текстів не існує, проте вони повинні бути. Ще 3,4 \% були переконані в тому, що жодних «класичних» (у вказаному сенсі) текстів або авторів не може існувати в принципі. Більша ж частина студентів та студенток вказали 1045 текстів чи їх авторів, які були розпізнані дослідниками: йдеться, переважно, про ситуації, коли вказувався або текст, який не вдалося атрибутувати, або автор, якого не знає навіть Google. Вказані тексти або автори вирізняються надзвичайним розмаїттям, адже в анкетах трапляються згадки про індійського брахмана Каутілью та християнського теолога Августина, акцентується увага на Конституції України та підручнику з історії 10 класу, як класичні творі розглядаються «1984» Орвелла та «Утопія» Мора, «Моя боротьба» Гітлера та «Капітал» Маркса, монографії професорськовикладацького складу та Білль про права, Біблія та «Лунь юй», роботи Габріеля Алмонда та публіцистика Сергія Кара-Мурзи, скрупульозні, витончені аналітичні конструкції Девіда Хелда та просякнуті очевидними фобіями тексти Андрія Паршева та Володимира «Істархова» тощо. Таке розмаїття потребувало певних класифікаційних принципів, які «витікали» з відповідних гіпотез.

Висунутими гіпотезами при цьому були такі: по-перше, сформований студентами та студентками перелік класичних текстів політичної науки - на відміну від будь-якого переліку професійних (закордонних) дослідників - буде характеризуватись меншим рівнем знайомства з сучасними (західними) політологічними роботами. По-друге, виходячи з факту вкоріненості політології в політичному контексті, з потенційної безлічі авторів/текстів, що традиційно вважаються «класичними», незалежно від того, сучасна це класика чи класика per se [22, c. 32], найбільш популярними будуть ті автори або роботи, які максимально комплементарні актуальним проблемам певного контексту (або регіону). По-третє, студенти та студентки не просто орієнтуються на проблеми свого безпосереднього оточення, а роблять вони це залежно від своїх ідеологічних уподобань. По-четверте, в умовах становлення політології в Україні та Молдові важливими для студентів та студенток можуть виявитись вітчизняні тексти та/або автори.

Відповідно, були виокремленні три групи респондентів: ті, хто в процесі опитування ідентифікував себе як прихильників ліберальної ідеології (надалі група «ліберали»); ті, хто вказали на свою близькість до національно-демократичної i/aбо націоналістичної течії (надалі група «націоналісти»); «інші», тобто ті, хто не ідентифікував себе як ліберала i/або «націоналіста» (надалі група «інші»). У найбільш загальному сенсі верифікація гіпотез передбачає виявлення нерівномірного розподілу авторів/текстів по трьох групам студентів та студенток в тому чи іншому випадку. Табл. 1-3 містять вибірковий перелік авторів (критерій - мінімум $2 \%$ голосів у будь-якій групі респондентів принаймні в одному з досліджуваних 3ВО), класифікованих залежно від ідеологічних уподобань студентів та студенток. Табл. 1 містить авторів від античності до так званого довгого XIX століття включно, тоді як табл. 2 присвячена авторам, що творили вже у XX-XXI столітті.

Змістовно ці дві таблиці розділяє успішна інституціоналізація більшості соціальних наук у минулому столітті. Внаслідок цього можна казати, у випадку Табл. 1, про відомі прізвища курсу «Історія політичної думки» 3 невизначеною дисциплінарною ідентичністю, а у випадку Табл. 2 - впевнено говорити про професійних політологів та авторів з інших наукових галузей.

Табл. 3 є попередньою та спрощеною класифікацією частини тих позаакадемічних впливів, які неминуче зазнають студентки та студенти під час свого фахового становлення.

Наведені вище дані дозволяють здійснити верифікацію гіпотез цього дослідження. По-перше, в цілому виправдалось припущення про низький рівень знайомства студентів та студенток із сучасними політологічними роботами. Особливо це стосується ХНУ, ЛНУ та ДУМу, де понад 70 \% «класиків» складають автори, які творили до XIX століття. Найбільш актуальними вбачаються постаті Макіавеллі, Платона та Арістотеля, що набрали від 34,7 \% в ЛНУ до 40,4 \% в ХНУ та 45,6 \% в ДУМ. Суперечать гіпотезі студентки та студенти ТНУ, де лише $41,1 \%$ вказали на авторів та/або тексти, що були створені до XX століття. Водночас таврійські респонденти виявляють найбільший інтерес до авторів XX-XXI століття - 34,7 \%. Це контрастує 3 даними по ДУМ (15,5\%), ХНУ (10,6\%) та особливо ЛНУ (7,1\%). Найбільшу увагу до відповідних робіт виявляють студенти старших курсів, що пов'язано, напевно, з початком спеціалізації (через обмеженість місця цієї статті, дані стосовно курсу навчання не були включені до відповідних таблиць. Проте, зважаючи на їхню важливість, у подальшому я буду згадувати загальні тенденції залежності відповідей студентів та студенток від курсу навчання. При цьому, молодшими курсами будуть позначатись I-II, а старшими - III-V). Відзначу регіональні відмінності в сприйнятті тих чи тих сучасних політологів як класичних. Так, ТНУ вирізняється винятковою увагою до Самуеля Гантінгтона, Збігнєва Бжезінського та Генрі Кіссинджера (30\% голосів респондентів), що разом з інтересом до Чарльза Капхена та Френсіса Фукуями (по 1,4 \%) свідчить про акцент на геополітичній проблематиці. Також несподіваною виглядає увага до Габріеля Алмонда, Роберта Даля та Джованні Сарторі в ДУМ (10,1\% в цілому) - у порівнянні з майже цілковитим ігноруванням цих авторів в Україні. Це доволі несподівана ситуація з огляду на наявність українських перекладів робіт Даля та Сарторі у 2001-2002 pp. 
«Класика» політичної науки до початку ХX століття, \%

\begin{tabular}{|c|c|c|c|c|c|c|c|c|c|c|c|c|c|c|c|c|c|}
\hline Студенти & \multicolumn{4}{|c|}{$\begin{array}{c}\text { ХНУ імені } \\
\text { В. Н. Каразіна }\end{array}$} & \multicolumn{4}{|c|}{$\begin{array}{c}\text { ЛНУ імені Івана } \\
\text { Франка }\end{array}$} & \multicolumn{4}{|c|}{$\begin{array}{c}\text { ТНУ імені } \\
\text { В. І. Вернадського }\end{array}$} & \multicolumn{4}{|c|}{ ДУМ (Кишинів) } & \multirow{2}{*}{ 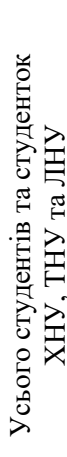 } \\
\hline Автори/тексти & 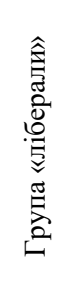 & 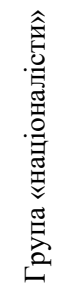 & 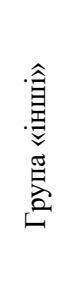 & 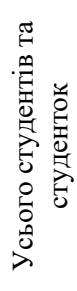 & 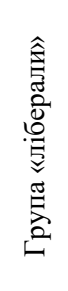 & 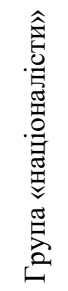 & 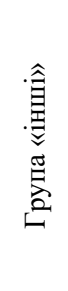 & 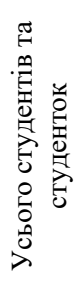 & 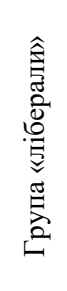 & 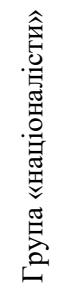 & 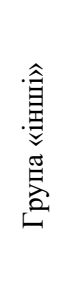 & 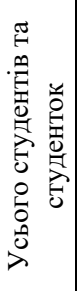 & 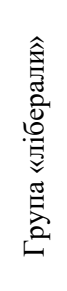 & 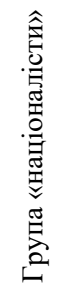 & 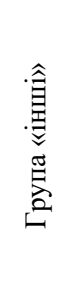 & 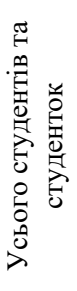 & \\
\hline Макіавеллі & 18 & 20 & 11,5 & 16,6 & 13,8 & 10,7 & 12,5 & 12,1 & 15,7 & 8,1 & 9,3 & 10,6 & 13,2 & 15,4 & 19,1 & 15,4 & 12,8 \\
\hline Платон & 12,4 & 12,5 & 11,5 & 12,2 & 11,5 & 13,9 & 16,7 & 14,1 & 3,9 & 8,1 & 6,2 & 6 & 18,4 & 7,7 & 17 & 16,1 & 11,1 \\
\hline Арістотель & 11,2 & 15 & 9,6 & 11,6 & 8 & 9,8 & 7,3 & 8,5 & 7,8 & 8,1 & 3,9 & 5,5 & 13,2 & 15,4 & 14,9 & 14,1 & 8,4 \\
\hline $\begin{array}{c}\text { Маркс та/або } \\
\text { Енгельс }\end{array}$ & 4,5 & 2,5 & 7,7 & 5 & 3,4 & 6,6 & 2,1 & 4,3 & 3,9 & 16,2 & 5,4 & 6,9 & 2,6 & 0 & 8,5 & 4 & 5,3 \\
\hline Вебер & 16,9 & 7,5 & 9,6 & 12,7 & 5,7 & 4,1 & 3,1 & 4,3 & 0 & 0 & 0 & 0 & 6,6 & 3,8 & 17 & 9,4 & 5,1 \\
\hline Гоббс & 3,4 & 5 & 7,7 & 5 & 12,6 & 4,1 & 7,3 & 7,5 & 2 & 0 & 1,6 & 1,4 & 0 & 0 & 0 & 0 & 5 \\
\hline $\begin{array}{l}\text { Мор та/або } \\
\text { Кампанелла }\end{array}$ & 1,1 & 2,5 & 1,9 & 1,7 & 0 & 2,5 & 6,3 & 3 & 11,8 & 5,4 & 4,7 & 6,5 & 0 & 3,8 & 2,1 & 1,3 & 3,7 \\
\hline Лок & 2,2 & 0 & 1,9 & 1,7 & 6,9 & 1,6 & 1 & 3 & 0 & 0 & 0 & 0 & 0 & 0 & 2,1 & 0,7 & 1,7 \\
\hline Гегель & 0 & 0 & 0 & 0 & 3,4 & 3,3 & 4,2 & 3,6 & 0 & 0 & 0 & 0 & 0 & 3,8 & 0 & 0,7 & 1,6 \\
\hline Ніцше & 3,4 & 2,5 & 1,9 & 2,8 & 1,1 & 2,5 & 2,1 & 2 & 0 & 0 & 0 & 0 & 0 & 0 & 0 & 0 & 1,6 \\
\hline Монтеск'є & 0 & 2,5 & 1,9 & 1,1 & 2,3 & 2,5 & 1 & 2 & 0 & 0 & 0,8 & 0,5 & 0 & 3,8 & 2,1 & 1,3 & 1,3 \\
\hline Токвіль & 2,2 & 0 & 0 & 1,1 & 1,1 & 1,6 & 3,1 & 2 & 0 & 0 & 0 & 0 & 5,3 & 0 & 0 & 2,7 & 1,1 \\
\hline Кант & 0 & 0 & 0 & 0 & 1,1 & 1,6 & 5,2 & 2,6 & 0 & 0 & 0 & 0 & 2,6 & 3,8 & 0 & 2 & 1,1 \\
\hline Цицерон & 1,1 & 0 & 0 & 0,6 & 0 & 0 & 2,1 & 0,7 & 2 & 5,4 & 1,6 & 2,3 & 0 & 0 & 0 & 0 & 1,1 \\
\hline Pycco & 2,2 & 2,5 & 0 & 1,7 & 0 & 0,8 & 0 & 0,3 & 0 & 0 & 0 & 0 & 3,9 & 0 & 0 & 2 & 0,6 \\
\hline Августин & 0 & 0 & 0 & 0 & 0 & 0 & 3,1 & 1 & 0 & 0 & 0 & 0 & 0 & 0 & 0 & 0 & 0,4 \\
\hline Дюркгайм & 0 & 0 & 0 & 0 & 0 & 0 & 0 & 0 & 0 & 0 & 0 & 0 & 0 & 0 & 2,1 & 0,7 & 0 \\
\hline Лебон & 0 & 0 & 0 & 0 & 0 & 0 & 0 & 0 & 0 & 0 & 0 & 0 & 6,6 & 7,7 & 2,1 & 5,4 & 0 \\
\hline $\begin{array}{c}\text { Парето, } \\
\text { Вільфредо }\end{array}$ & 0 & 0 & 0 & 0 & 0 & 0 & 0 & 0 & 2 & 0 & 0 & 0,5 & 0 & 0 & 0 & 0 & 0,1 \\
\hline $\begin{array}{l}\text { Міхельс, } \\
\text { Роберт }\end{array}$ & 0 & 0 & 0 & 0 & 0 & 0 & 1 & 0,3 & 3,9 & 0 & 0 & 0,9 & 0 & 0 & 0 & 0 & 0,4 \\
\hline Усього & 78,6 & 72,5 & 65,2 & 73,8 & 70,9 & 65,6 & 78,1 & 71,3 & 53 & 51,3 & 33,5 & 41,1 & 72,4 & 65,2 & 87 & 75,8 & 62,4 \\
\hline
\end{tabular}


Таблиця 2

Сучасна класика політичної науки, \%

\begin{tabular}{|c|c|c|c|c|c|c|c|c|c|c|c|c|c|c|c|c|c|}
\hline \multirow{2}{*}{$\begin{array}{c}\text { Студенти } \\
\\
\text { Автори/тексти }\end{array}$} & \multicolumn{4}{|c|}{$\begin{array}{c}\text { ХНУ імені } \\
\text { В. Н. Каразіна }\end{array}$} & \multicolumn{4}{|c|}{$\begin{array}{c}\text { ЛНУ імені Івана } \\
\text { Франка }\end{array}$} & \multicolumn{4}{|c|}{$\begin{array}{c}\text { ТНУ імені } \\
\text { В. І. Вернадського }\end{array}$} & \multicolumn{4}{|c|}{ ДУМ (Кишинів) } & \multirow{2}{*}{ 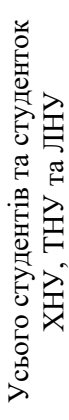 } \\
\hline & 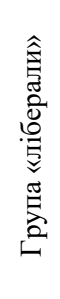 & 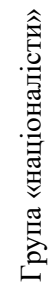 & 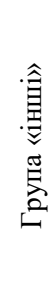 & 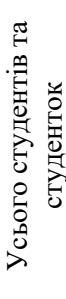 & 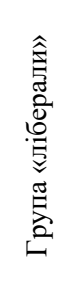 & 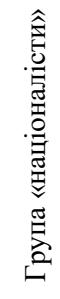 & 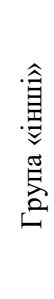 & 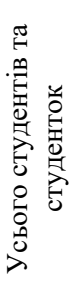 & 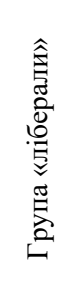 & 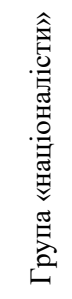 & 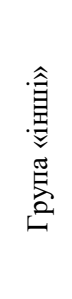 & 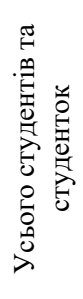 & 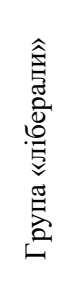 & 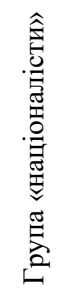 & 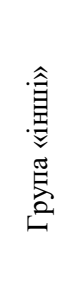 & 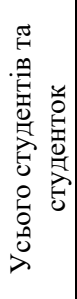 & \\
\hline \multicolumn{18}{|c|}{ АВТОРИ ПЕРШОЇ ПОЛОВИНИ ХХ СТОЛІТТЯ } \\
\hline Шмітт, Карл & 2,2 & 2,5 & 1,9 & 2,2 & 0 & 0 & 0 & 0 & 0 & 0 & 0 & 0 & 0 & 0 & 0 & 0 & 0,6 \\
\hline $\begin{array}{c}\text { Ортега-і-Гасет, } \\
\text { Хосе }\end{array}$ & 0 & 0 & 0 & 0 & 0 & 0 & 2,1 & 0,7 & 0 & 0 & 0 & 0 & 0 & 0 & 0 & 0 & 0,3 \\
\hline \multicolumn{18}{|c|}{ ПОЛІтолОГИ дРУГОї ПОЛОВИНИ ХХ стОЛІтТЯ } \\
\hline $\begin{array}{c}\text { Гантінгтон, } \\
\text { Самуель }\end{array}$ & 1,1 & 2,5 & 1,9 & 1,7 & 2,3 & 0,8 & 0 & 1 & 7,8 & 10,8 & 11,6 & 10,6 & 5,3 & 3,8 & 2,1 & 4 & 4,1 \\
\hline $\begin{array}{l}\text { Бжезінський, } \\
\text { Збігнєв }\end{array}$ & 0 & 2,5 & 0 & 0,6 & 2,3 & 0 & 0 & 0,7 & 11,8 & 10,8 & 14,7 & 13,4 & 0 & 0 & 2,1 & 0,7 & 4,6 \\
\hline $\begin{array}{c}\text { Кіссинджер, } \\
\text { Генрі }\end{array}$ & 0 & 0 & 0 & 0 & 0 & 0 & 0 & 0 & 2 & 2,7 & 8,5 & 6 & 0 & 0 & 0 & 0 & 1,8 \\
\hline $\begin{array}{l}\text { Дюверже, } \\
\text { Моріс }\end{array}$ & 0 & 0 & 0 & 0 & 4,6 & 2,5 & 2,1 & 3 & 0 & 0 & 0 & 0 & 0 & 0 & 0 & 0 & 1,3 \\
\hline $\begin{array}{l}\text { Валлерстайн, } \\
\text { Іммануїл }\end{array}$ & 2,2 & 2,5 & 1,9 & 2,2 & 0 & 0 & 0 & 0 & 0 & 2,7 & 0,8 & 0,9 & 0 & 0 & 0 & 0 & 0,9 \\
\hline $\begin{array}{l}\text { Фукуяма, } \\
\text { Френсіс }\end{array}$ & 0 & 2,5 & 0 & 0,6 & 1,1 & 0,8 & 0 & 0,7 & 2 & 2,7 & 0,8 & 1,4 & 1,3 & 0 & 0 & 0,7 & 0,9 \\
\hline $\begin{array}{l}\text { Капхен, } \\
\text { Чарльз }\end{array}$ & 0 & 0 & 0 & 0 & 0 & 0 & 0 & 0 & 3,9 & 0 & 0,8 & 1,4 & 0 & 0 & 0 & 0 & 0,4 \\
\hline $\begin{array}{l}\text { Алмонд, } \\
\text { Габріель }\end{array}$ & 2,2 & 0 & 0 & 1,1 & 0 & 0 & 0 & 0 & 0 & 0 & 0 & 0 & 1,3 & 3,8 & 4,3 & 2,7 & 0,3 \\
\hline Хелд, Девід & 0 & 0 & 3,8 & 1,1 & 0 & 0 & 0 & 0 & 0 & 0 & 0 & 0 & 0 & 0 & 0 & 0 & 0,3 \\
\hline $\begin{array}{l}\text { Воллін, } \\
\text { Шелдон }\end{array}$ & 0 & 0 & 0 & 0 & 0 & 0 & 0 & 0 & 2 & 0 & 0 & 0,5 & 0 & 0 & 0 & 0 & 0,1 \\
\hline Даль, Роберт & 0 & 0 & 0 & 0 & 0 & 0 & 0 & 0 & 0 & 0 & 0 & 0 & 5,3 & 0 & 2,1 & 3,4 & 0 \\
\hline $\begin{array}{l}\text { Сарторі, } \\
\text { Джованні }\end{array}$ & 0 & 0 & 0 & 0 & 0 & 0 & 0 & 0 & 0 & 0 & 0 & 0 & 7,9 & 0 & 0 & 4 & 0 \\
\hline \multicolumn{18}{|c|}{ АВТОРИ ДРУГОЇ ПОЛОВИНИ ХХ СТОЛІтТЯ } \\
\hline Фромм, Еріх & 0 & 0 & 0 & 0 & 0 & 0,8 & 2,1 & 1 & 0 & 0 & 0 & 0 & 0 & 0 & 0 & 0 & 0,4 \\
\hline Бурдьє, П’єр & 1,1 & 2,5 & 0 & 1,1 & 0 & 0 & 0 & 0 & 0 & 0 & 0 & 0 & 0 & 0 & 0 & 0 & 0,3 \\
\hline Бергер, Пітер & 0 & 0 & 0 & 0 & 0 & 0 & 0 & 0 & 0 & 2,7 & 0 & 0,5 & 0 & 0 & 0 & 0 & 0,1 \\
\hline Усього & 8,8 & 15 & 9,5 & 10,6 & 10,3 & 4,9 & 6,3 & 7,1 & 29,5 & 32,4 & 37,2 & 34,7 & 21,1 & 7,6 & 10,6 & 15,5 & 16,4 \\
\hline
\end{tabular}


Таблиця 3

Позаакадемічні впливи політичної науки, \%

\begin{tabular}{|c|c|c|c|c|c|c|c|c|c|c|c|c|c|c|c|c|c|}
\hline Студенти & \multicolumn{4}{|c|}{$\begin{array}{c}\text { ХНУ імені } \\
\text { В. Н. Каразіна }\end{array}$} & \multicolumn{4}{|c|}{$\begin{array}{c}\text { ЛНУ імені Івана } \\
\text { Франка }\end{array}$} & \multicolumn{4}{|c|}{$\begin{array}{c}\text { ТНУ імені } \\
\text { В. I. Вернадського }\end{array}$} & \multicolumn{4}{|c|}{ ДУМ (Кишинів) } & \multirow{2}{*}{ 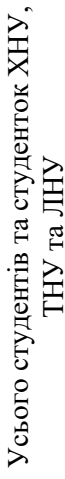 } \\
\hline Автори/тексти & 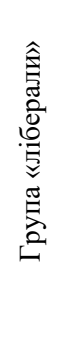 & 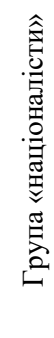 & 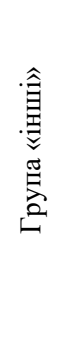 & 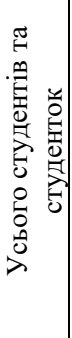 & 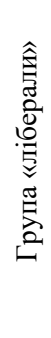 & 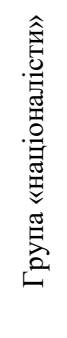 & 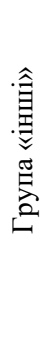 & 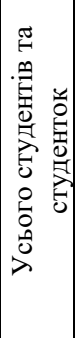 & 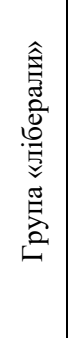 & 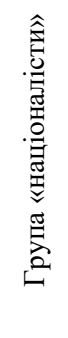 & 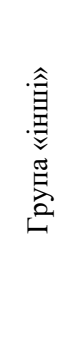 & 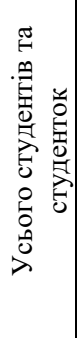 & 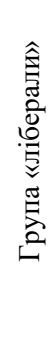 & 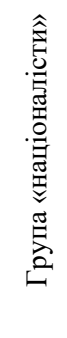 & 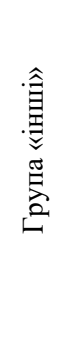 & 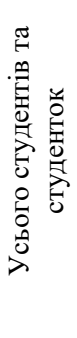 & \\
\hline \multicolumn{18}{|c|}{ СУЧАСНА ПОЛІТОЛОГІЧНА ПУБЛІЦИСТИКА } \\
\hline Паршев, Андрій & 0 & 0 & 0 & 0 & 0 & 0 & 0 & 0 & 5,9 & 2,7 & 4,7 & 4,6 & 0 & 0 & 0 & 0 & 1,4 \\
\hline Уткін, Анатолій & 0 & 0 & 0 & 0 & 0 & 0 & 0 & 0 & 0 & 0 & 3,1 & 1,8 & 0 & 0 & 0 & 0 & 0,6 \\
\hline Красін, Юрій & 0 & 2,5 & 0 & 0,6 & 0 & 0 & 0 & 0 & 0 & 0 & 0 & 0 & 0 & 0 & 0 & 0 & 0,1 \\
\hline Кара-Мурза, Сергій & 0 & 0 & 0 & 0 & 0 & 0 & 0 & 0 & 0 & 0 & 0 & 0 & 0 & 3,8 & 0 & 0,7 & 0 \\
\hline Перкінс, Джон & 0 & 0 & 0 & 0 & 0 & 0 & 0 & 0 & 0 & 0 & 0 & 0 & 0 & 3,8 & 0 & 0,7 & 0 \\
\hline \multicolumn{18}{|c|}{ ПИСЬМЕННИКИ } \\
\hline Орвелл, Джордж & 2,2 & 2,5 & 0 & 1,7 & 0 & 0 & 0 & 0 & 0 & 5,4 & 0,8 & 1,4 & 0 & 3,8 & 0 & 0,7 & 0,9 \\
\hline Замятін, Свген & 0 & 0 & 0 & 0 & 0 & 0 & 0 & 0 & 0 & 2,7 & 0,8 & 0,9 & 0 & 0 & 0 & 0 & 0,3 \\
\hline \multicolumn{18}{|c|}{ ВІТЧИЗНЯНІ ПОЛІТИЧНІ ДІЯЧІ ТА ПИСЬМЕННИКИ } \\
\hline Донцов, Дмитро & 0 & 0 & 0 & 0 & 0 & 0,8 & 1 & 0,7 & 0 & 0 & 0 & 0 & 0 & 0 & 0 & 0 & 0,3 \\
\hline $\begin{array}{l}\text { Михальчишин, } \\
\text { Юрій }\end{array}$ & 0 & 0 & 0 & 0 & 0 & 0,8 & 0 & 0,3 & 0 & 0 & 0 & 0 & 0 & 0 & 0 & 0 & 0,1 \\
\hline $\begin{array}{c}\text { Рудницький, } \\
\text { Михайло }\end{array}$ & 0 & 0 & 0 & 0 & 0 & 0,8 & 0 & 0,3 & 0 & 0 & 0 & 0 & 0 & 0 & 0 & 0 & 0,1 \\
\hline $\begin{array}{c}\text { Сціборський, } \\
\text { Микола }\end{array}$ & 0 & 0 & 0 & 0 & 0 & 0,8 & 0 & 0,3 & 0 & 0 & 0 & 0 & 0 & 0 & 0 & 0 & 0,1 \\
\hline Франко, Іван & 0 & 0 & 0 & 0 & 0 & 0,8 & 0 & 0,3 & 0 & 0 & 0 & 0 & 0 & 0 & 0 & 0 & 0,1 \\
\hline Серебреан, Олег & 0 & 0 & 0 & 0 & 0 & 0 & 0 & 0 & 0 & 0 & 0 & 0 & 1,3 & 3,8 & 0 & 1,3 & 0 \\
\hline $\begin{array}{l}\text { Кодряну, } \\
\text { Корнеліу }\end{array}$ & 0 & 0 & 0 & 0 & 0 & 0 & 0 & 0 & 0 & 0 & 0 & 0 & 0 & 3,8 & 0 & 0,7 & 0 \\
\hline \multicolumn{18}{|c|}{ ЗАКОРДОННІ ПОЛІТИЧНІ ДІЯЧІ } \\
\hline Гітлер & 1,1 & 2,5 & 1,9 & 1,7 & 1,1 & 6,6 & 1 & 3,3 & 3,9 & 0 & 0,8 & 1,4 & 0 & 7,7 & 2,1 & 2 & 2,3 \\
\hline $\begin{array}{c}\text { Бьюкенен, } \\
\text { Джордж }\end{array}$ & 0 & 0 & 0 & 0 & 0 & 0 & 0 & 0 & 2 & 2,7 & 2,3 & 2,3 & 0 & 0 & 0 & 0 & 0,7 \\
\hline Ленін & 0 & 0 & 0 & 0 & 1,1 & 0 & 0 & 0,3 & 0 & 2,7 & 0 & 0,5 & 0 & 0 & 0 & 0 & 0,3 \\
\hline Усього & 3,3 & 7,5 & 1,9 & 4 & 2,2 & 10,6 & 2 & 5,5 & 11,8 & 16,2 & 12,5 & 12,9 & 1,3 & 26,7 & 2,1 & 6,1 & 7,3 \\
\hline
\end{tabular}


Для пояснення «випадку Криму», можна висунути таке положення: Крим - релігійно та етнічно гетерогенний регіон, який зазнавав помітного іноземного впливу. Через це для нього характерний високий рівень поляризації щодо геополітичних орієнтацій. Тобто інтерес до геополітичної проблематики $є$ засобом самоідентифікації студентів-політологів в науковому дискурсі. Водночас контраргументом можна вважати те, що роботи Самюеля Гантінгтона, Збігнєва Бжезінського i Генрі Кіссинджера досить наполегливо пропонуються студентам ТНУ як монографії, обов'язкові для конспектування. На мою думку, не варто переоцінювати студентську пластичність, оскільки на старших курсах пріоритет може віддаватися публікаціям, які «входили в резонанс» із загальнонаціональними чи регіональними проблемами, та водночас інтерпретуються з погляду прийнятних для студентів ідеологічних схем (розуміння). Саме в цьому випадку особисті якості викладачів або пропоновані ними книги можуть відігравати помітну роль. Скажімо, в ЛНУ на той час працював один з найсильніших пострадянських фахівців в області партій і партійних систем, але популярність, наприклад, Моріса Дюверже серед студентів цього ЗВО становила $3 \%$. Пояснення цьому полягає в тому, що Моріс Дюверже або Джованні Сарторі, при всій епохальності їх наукової спадщини, не настільки були зажаданими (студентами) в конкретному суспільно-політичному контексті Львова. Чого, судячи з усього, не можна сказати про геополітичні роботи та їхніх авторів в Криму. У цілому популярність російських і радянських авторів (Андрій Паршев, Анатолій Уткін - див. табл. 3) в Криму є, очевидно, відображенням полярності геополітичних орієнтацій студентів-політологів ТНУ.

Таким чином, питома вага сучасних закордонних політологів, які вказують ступінь знайомства з сучасними тенденціями політичної науки, $\epsilon$ незначною для двох 3 трьох українських ЗВО та кишинівського. Це вочевидь суперечить оптимістичній думці Марії Кармазіної, згідно з якою «маємо підстави твердити, що розвиток політичної науки на вітчизняних теренах $\epsilon$, найперше, наслідком рецепції західного знання про політику і політичне» [12, с. 17]. Відсутність своєрідної імплементації надбань сучасної політології в студентські навчальні практики водночас і відображає, і підсилює похмурий погляд на загальний стан української політології, що постає в статтях Олександра Старіша [23], Сергія Куделі [14], Юрія Мацієвського [15], Оксани Шевель [5] та Анатолія Круглашова [2]. Щоправда, тут можливе ще одне пояснення, а саме: інтереси студентів та студенток обумовлені інтересами викладачів, у багатьох випадках добре ознайомлених з сучасною політологічною класикою внаслідок участі узакордонних освітніх та наукових програмах. Обгрунтованості цій гіпотези також додає те, що інтелектуальні інтереси найбільш впливових професорів кафедр політології Харкова і Львова, що завдяки своїй науковій ієрархії багато в чому впливають на теми курсових і дипломних робіт, стосуються історії (політичних) ідей, епістемології і методології науки.

Разом з тим не слід переоцінювати ступінь впливу на студентів та студенток їхіх викладачів. У цьому сенсі симптоматичними є результати верифікації двох наступних гіпотез. Йдуться, зокрема, про ідеологічні та регіональні відмінності виокремлення «класики», що підтверджує припущення про залежність між політичними та науковими інтересами. Найяскравіше це проявляється на прикладі кола читання «націоналістів». Так, львівські та сімферопольські «націоналісті» цікавляться Марксом/Енгельсом (16,2\% та 6,6 \% відповідно), тоді як в інших ЗВО вони асоціюються з «іншими» ідеологіями. Ще більш несподіваним є інтерес харківських (2,5\%), львівських $(6,6 \%)$ та кишинівських $(7,7 \%)$ «націоналістів» до Гітлера та його роботи «Моя боротьба», тоді як в ТНУ він цікавий майже винятково «лібералам» $(3,9 \%)$. Нi Маркс/Енгельс, ні Гітлер жодним чином не входить до кола інтересів професорів та доцентів досліджуваних спільнот. Очевидно, що мова йде про свідому, ідеологічно обумовлену селекцію, коли послідовно відкидаються всі тексти, які не дають можливості вписати власну незадоволеність в опозиційну/радикальну/протестну ідеологію. Це суттєво відрізняється від студентського «лібералізму», який багато в чому являє собою до кінця так і не вистраждану ідеологічну позицію (див., наприклад, [18, с. 233-234]), а тому, судячи з табл. 1, може виявитись більш пластичним до інтересів викладачів i/або абстрактних формулювань про свободу і права людини. Можлива також інтерпретація, відповідно до якої, «ліберали» заново відкривають для себе авторів, які узгоджуються з їхніми ідеологічними установками. Частково це підтверджується тим, що автори античності, інтерес до яких характерний для львівських і харківських студентів-політологів на старших курсах, не перебувають у центрі дослідницьких інтересів професорсько-викладацького складу відповідних кафедр.

Своєю чергою, своєрідний марксистський ренесанс в Україні можна пояснити тим, що він може виступати науковим обгрунтуванням протестних рухів і, відповідно, свідченням зростаючого невдоволення існуючим станом речей. Це породжує інтерес до доктрин, які ставлять на перше місце ідею соціальної справедливості. Можливо, це не тільки політичний, але і певний інтелектуальний тренд. Стосовно Гітлера, можна припустити, що інтерес до нього як до представника ультраправої ідеології також був обумовлений розчаруванням «в існуючих ліберальних моделях на тлі загострення соціально-політичних проблем в умовах економічної кризи» [18, с. 234]. Зазначу, що під час опитування не було виявлено статично значущого рівня антисемітизму серед студентів та студенток.

Нарешті загальною тенденцією для всіх досліджених політологічних спільнот є практично повна відсутність інтересу до інтелектуальних здобутків вітчизняних політиків і політологів (хоча кишинівські студентки та студенти проявляють трохи більший інтерес до власних коренів, судячи з обсягу уваги до Олега Серебреана та Корнеліу Кодряну (див. табл.3). Це досить дивно, з огляду, з одного боку, на переконаність 
переважної більшості респондентів упершорядній важливості внутрішніх проблем, таких як бідність, корупція, дефіцит демократії, легітимність влади й проблема мови, з іншого боку,- широку поширеність $\mathrm{i}$ доступність даної категорії текстів, які присутні і на ринку, і в бібліотеках, і в інтернеті. Ба більше, український націоналізм традиційно пов'язується з низкою знакових фігур (Дмитро Донцов, В'ячеслав Липинський та ін.), які виявились абсолютно нецікавими місцевим «націоналістам». Зазначені дані змушують зробити висновок про вкрай низьку оцінку ступеня корисності даних текстів для майбутніх фахівцівполітологів, навіть якщо останні ідентифікують себе з «націоналістичними» ідеологіями.

Цілковите ігнорування власних наукових та політичних традицій з боку студентів та студенток робить актуальною (пост)колоніальну інтерпретацію української та молдавської політології. Зокрема, один 3 найбільших знавців історії української політології під час інтерв’ю описав ситуацію з запереченням традицій національної політичної думки в біблійних термінах: «Я говорю тільки про політичні науки - Ви знаєте, тут [ніякого] сплеску не було ... Наше видавництво, “Кальварія”, хотіло видати Донцова в п’яти томах, але грошей вистачило тільки на один ... Мені здається, що зараз період, коли розкидають каміння». Про ступінь незацікавленості в розробці власної політологічної традиції можна судити також по оцінці впливу, що чиниться порівняно невеликою книгою цитованого респондента з історії політичної думки України. Написана в середині 1990-х рр., вона удостоїлася такої характеристики з боку київського професора, зцілком зрозумілою гордістю повтореною моїм співрозмовником в 2013 р.: «“Ти не розумієш, наскільки ти років перекрив кисень іншим". Так ось я поки перекрив».

У цілому, процес формування ідентичності одночасно через ідентифікацію з іншими традиціями і заперечення власних «коренів» можна описати за допомогою поняття внутрішньої колонізації: «колонізація завжди пов'язана зі спробою освоїти чуже», тоді як «відчуття себе чужим серед своїх» є «постійною формою невдоволення і протесту, пов'язаних з ситуацією внутрішньої колонізації» [25, с. 90]. Звісно, опитування не дає змоги стверджувати, якою мірою студентам властиво «почуття чужорідності у своїй країні, відчуття зупиненого часу i критика наслідувальної культури» [25, с. 30] (проблема постколоніальності української політичної науки розглядалась, зокрема, в нашій роботі [19, с. 271-287]). Проте дані того самого опитування добре узгоджуються з раніше згаданими оглядами навчальних посібників 1990-х - початку 2000-х рр., коли, зокрема, Олена Раздіна показала, що найбільш часто цитовані в них роботи (не рахуючи класиків на кшталт Платона) належали авторам з СНД і західним вченим, i лише в останню чергу - українським. Це означає, що українські та молдавські студенти від самого початку звикають до того, що власне політичне життя та способи його категоризації презентують античні, закордонні та пострадянські (переважно, російські) вчені, політики та навіть письменники. Саме вони, попри очевидні геополітичні конфлікти інтересів, розповідають, що є справжньою політичною наукою, політикою, політичним режимом, політичним минулим та майбутнім тощо.

Висновки. У даній розвідці була здійснена верифікація кількох гіпотез, спрямованих на виявлення зв'язків між політичними та науковими інтересами студентів та студенток України та Молдови. У цілому, можна зробити висновок, що на студентському рівні українську та молдавську політології можна описати словами, що раніше були висловлені щодо їхнього професійного, академічного рівня: вони перебувають «в пошуках власної суб'єктності, виступаючи в ролі самопроголошеної “колонії” західної або російської “наукової метрополії”» [19, с. 283]. Це ставить на чергу порядку денного потребу стати цікавими для себе i зробити відповідні політичні науки по-справжньому актуальними для власних суспільств, виступивши виробниками оригінального знання, а не ретрансляторами чужого досвіду. З'ясуванню обгрунтованості цієї можливості будуть присвячені подальші мої публікації.

Бібліографічний список:

1.Goodin R. The State of the Discipline, the Discipline of the State The Oxford Handbook of Political Science. / Goodin R. (Ed.), Oxford University Press, 2009. P. 1-57. DOI: 10.1093/oxfordhb/9780199604456.013.0001

2.Kruglashov A. Ukrainian Political Science: From Quantity to Quality. Political Science in Central and Eastern Europe. Diversity and Convergence. Rainer Eisfeld \& Leslie Pal (eds.). Verlag Barbara Budrich, 2010, P. 291-304. DOI:10.2307/j.ctvhhhhgs.23

3.Masuoka N., Grofman B., Feld S. L. The Political Science 400: A 20-Year Update. PS: Political Science and Politics. 2007. P. 133-145. DOI: 10.1017/S1049096507070199

4.Ravecca P. The Politics of Political Science. Re-writing Latin American Experiences. New York: Routledge, 2019. $292 \mathrm{p}$.

5.Shevel O. Ukrainian Political Science and the Study of Ukraine within American Political Science: How Similar, How Different? Journal of Ukrainian Politics and Society. 2015. No.1 P. $23-32$.

6.Sigelman L. Top twenty commentarie. American Political Science Review. 2006. Vol. 100, № 4. P. 667-688.

7.Sommit A., Tanenhaus J. American Political Science. A Profile of a Discipline. New York: Prentice Hall, 1964. $173 \mathrm{p}$.

8.Sommit A., Tanenhaus J. The Development of American Political Science. New York: Irvington Publishers, 1982. $246 \mathrm{p}$.

9.Гудин Р. И., Клингеманн Х.-Д. Политическая наука как дисциплина. Политическая наука: новые направления. Москва: Вече, 1999. С. 29-69. 
10.Дмитриев Т. Классика и история политической философии: случай Лео Штрауса. Классика и классики в сочиальном и гуманитарном знании. Москва: Новое литературное обозрение, 2009. С. 155-180.

11.Капелюшников Р. Деконструируя «классика» (заметки на полях «Великой трансформации»). Классика и классики в соииальном и гуманитарном знани. Москва: Новое литературное обозрение, 2009. C. 121-154.

12.Кармазіна М. Історія дисципліни / редкол.: чл.-кор. НАН України О. Рафальський (голова), д-р політ. наук М. Кармазіна, д-р іст. наук О. Майборода : Політична наука в Украӥні. 1991-2016: у 2 m. T. 1. Політична наука: західні тренди розвитку й украӥнська специфіка / автор передм. О. Рафальський : відп. ред. і упоряд. М. Кармазіна. Київ : Парламентське видавництво, 2016. С.17-44.

13.Классика и классики в социальном и гуманитарном знании. Москва: Новое литературное обозрение, 2009. $536 \mathrm{c}$.

14.Куделя С. Чи можлива в Україні політична наука? Критика, 2012. № 1-2. С. 24-25.

15.Мацієвський Ю. Чому в нас немає політичної науки. Критика, 2012. №6. С. 10-12.

16.Муляр В. І., Венгерська В. О., Сухачов С. Я. Аналіз навчальної літератури з політичної науки, виданої в Центральном і Західном регіонах України. Политическая наука в Украине: становление и перспективы. Симферополь, 2002. С. 97-143.

17.Николко М. В. Институционализация политической науки в Украине: анализ периодических изданий. Политическая наука в Украине: становление и перспективы. Симферополь, 2002. С. 40-52.

18.Осин В., Зеленски А., Шуляк С. Власть и знание на постсоветском пространстве: политический режим, научная степень, идеология и карьера в Украине и Молдове. Вильнюс, 2014. 376 с.

19.Осин В. Наука в новом мире: Три сюжета генезиса региональной политологии в постсоветской Украине. Ab Imperio. Studies of New Imperial History and Nationalism in the Post-Soviet Space, 2015. №. 4. C. 239-293.

20.Политическая наука в Украине: становление и перспективы. Симферополь, 2002. 344 с.

21.Раздина Е. В. Анализ учебной литературы по политической науке, используемой в вузах восточного региона Украины. Политическая наука в Украине: становление и перспективы. Симферополь, 2002. С. $72-96$.

22.Савельева И., Полетаев А. Классическое наследие. Москва: ГУ-ВШЭ, 2010. 336 с

23.Старіш О. Політична наука в Україні: 20 років незалежности. Критика, 2012. № 9-10. С. 27-29.

24.Филатов А. С. Анализ учебной литературы по политической науке, используемой в ВУЗах Украины. Политическая наука в Украине: становление и перспективы. Симферополь, 2002. С. 144-186.

25.Эткинд А. Внутренняя колонизация. Имперский опыт России. Москва: Новое литературное обозрение, 2014. 448c.

References:

1.Goodin R. The State of the Discipline, the Discipline of the State The Oxford Handbook of Political Science. / Goodin R. (Ed.), Oxford University Press, 2009. P. 1-57. DOI: 10.1093/oxfordhb/9780199604456.013.0001

2.Kruglashov A. Ukrainian Political Science: From Quantity to Quality. Political Science in Central and Eastern Europe. Diversity and Convergence. Rainer Eisfeld \& Leslie Pal (eds.). Verlag Barbara Budrich, 2010, P. 291-304. DOI:10.2307/j.ctvhhhhgs.23

3.Masuoka N., Grofman B., Feld S. L. The Political Science 400: A 20-Year Update. PS: Political Science and Politics. 2007. P. 133-145. DOI: 10.1017/S1049096507070199

4.Ravecca P. The Politics of Political Science. Re-writing Latin American Experiences. New York: Routledge, 2019. 292 p.

5.Shevel O. Ukrainian Political Science and the Study of Ukraine within American Political Science: How Similar, How Different? Journal of Ukrainian Politics and Society. 2015. No.1 P. 23-32.

6.Sigelman L. Top twenty commentarie. American Political Science Review. 2006. Vol. 100, № 4. P. 667-688.

7.Sommit A., Tanenhaus J. American Political Science. A Profile of a Discipline. New York: Prentice Hall, 1964. $173 \mathrm{p}$.

8.Sommit A., Tanenhaus J. The Development of American Political Science. New York: Irvington Publishers, 1982. $246 \mathrm{p}$.

9.Gudin R. I., Klingemann H.-D. Politicheskaja nauka kak disciplina. Politicheskaja nauka: novye napravlenija. Moskva: Veche, 1999. S. 29-69.

10.Dmitriev T. Klassika i istorija politicheskoj filosofii: sluchaj Leo Shtrausa. Klassika i klassiki v social'nom $i$ gumanitarnom znanii. Moskva: Novoe literaturnoe obozrenie, 2009. S. 155-180.

11.Kapeljushnikov R. Dekonstruiruja «klassika» (zametki na poljah «Velikoj transformacii»). Klassika $i$ klassiki v social'nom i gumanitarnom znani. Moskva: Novoe literaturnoe obozrenie, 2009. S. 121-154.

12.Karmazina M. Istorija dyscypliny / redkol.: chl.-kor. NAN Ukrajiny O. Rafaljsjkyj (gholova), d-r polit. nauk M. Karmazina, d-r ist. nauk O. Majboroda : Politychna nauka v Ukrajini. 1991-2016 : u 2 t. T. 1. Politychna nauka: zakhidni trendy rozvytku j ukrajinsjka specyfika / avtor peredm. O. Rafaljsjkyj : vidp. red. i uporjad. M. Karmazina. Kyjiv : Parlamentsjke vydavnyctvo, 2016. S.17-44.

13.Klassika i klassiki v social'nom i gumanitarnom znanii. Moskva: Novoe literaturnoe obozrenie, 2009. $536 \mathrm{~s}$. 14.Kudelja S. Chy mozhlyva v Ukrajini politychna nauka? Krytyka, 2012. \# 1-2. S. $24-25$. 
15.Macijevsjkyj Ju. Chomu v nas nemaje politychnoji nauky. Krytyka, 2012. \# 6. S. 10-12.

16.Muljar V. I., Venghersjka V. O., Sukhachov S. Ja. Analiz navchaljnoji literatury z politychnoji nauky, vydanoji v Centraljnom i Zakhidnom reghionakh Ukrajiny. Politicheskaja nauka v Ukraine: stanovlenie i perspektivy. Simferopol', 2002. S. 97-143.

17.Nikolko M. V. Institucionalizacija politicheskoj nauki $\mathrm{v}$ Ukraine: analiz periodicheskih izdanij. Politicheskaja nauka v Ukraine: stanovlenie i perspektivy. Simferopol', 2002. S. 40-52.

18.Osin V., Zelenski A., Shuljak S. Vlast' i znanie na postsovetskom prostranstve: politicheskij rezhim, nauchnaja stepen', ideologija i kar'era v Ukraine i Moldove. Vil'njus, 2014. $376 \mathrm{~s}$.

19.Osin V. Nauka v novom mire: Tri sjuzheta genezisa regional'noj politologii v postsovetskoj Ukraine. Ab Imperio. Studies of New Imperial History and Nationalism in the Post-Soviet Space, 2015. №.4. S. 239-293.

20.Politicheskaja nauka v Ukraine: stanovlenie i perspektivy. Simferopol', 2002. 344 s.

21.Razdina E. V. Analiz uchebnoj literatury po politicheskoj nauke, ispol'zuemoj v vuzah vostochnogo regiona Ukrainy. Politicheskaja nauka v Ukraine: stanovlenie i perspektivy. Simferopol', 2002. S. 72-96.

22.Savel'eva I., Poletaev A. Klassicheskoe nasledie. Moskva: GU-VShJe, 2010. 336 s.

23.Starish O. Politychna nauka v Ukrajini: 20 rokiv nezalezhnosty. Krytyka, 2012. \#9-10. S. 27-29.

24.Filatov A. S. Analiz uchebnoj literatury po politicheskoj nauke, ispol'zuemoj v VUZah Ukrainy. Politicheskaja nauka v Ukraine: stanovlenie i perspektivy. Simferopol', 2002. S. 144-186.

25.Jetkind A. Vnutrennjaja kolonizacija. Imperskij opyt Rossii. Moskva: Novoe literaturnoe obozrenie, 2014. $448 \mathrm{~s}$.

DOI 10.31558/2617-0248.2021.6.7

УДК 323:81'272:32(001)

\title{
ІНСТИТУЦЙНІ ОСНОВИ МОДЕРНІЗАЦІЇ ПОЛІТИЧНИХ МЕРЕЖ МОДЕЛІ МОВНОЇ ПОЛІТИКИ
}

\author{
ORCID ID: https://orcid.org/0000-0002-5728-0686 \\ Савойська С. В., доктор наук в галузі політології, професор Міжрегіональної академії \\ управління персоналом
}

Досліджуються інституційні основи модернізації моделі мовної політики. Обґрунтовано, що інституційною основою модернізації політичних мереж моделі мовної політики є українська або ін. мова (у різні часи - це києворуська, церковнослов'янська, староукраїнська, руська та ін.) як державна інституція, яка у XV-му та XVI-му ст. використовувалася у церковних перекладах та у службі Божій. Мовна політика модернізації торкнулася церковної сфери саме тоді, коли українська церква стала незалежною, коли священики мали можливість проводити службу Божу та читати проповіді українською (церковнослов'янською) мовою.

Дається визначення поняття "модернізація», що розуміємо як: культурні і демократичні зміни; оновлення діяльності певної інституції чи галузі, яка несе значні рудименти минулого та підпорядкована його завданням; глибокі зміни в освітньому авторитарному світогляді; перегляд принципів функціонування освіти, ії реформування відповідно до нових вимог. Охарактеризовано діяльність тих інститутів, які незалежна Українська держава отримала у спадок від СРСР, однією із причин розпаду якого $€$ те, що ця наддержава намагалася побудувати безнаціональне одномовне суспільство, яке у нових демократичних умовах не може функціонувати конструктивно та повноцінно діяти. 3'ясовано, що ігнорування національних, зокрема мовних факторів, виявилося одним із чинників нежиттєздатності імперії, позаяк багатонаціональній державі потрібен плюралізм політичних та ідеологічних думок.

Акцентується увага на тому, що з відновленням незалежності нові демократичні інститути (інститут Президента, законодавчий інститут, яким $є$ в Україні Верховна Рада, виконавчий інститут - Кабінет Міністрів, а також мережа судових, комунікаційних, управлінських, освітніх та ін. інститутів) визначили тип побудови моделі мовної політики в Україні, яка є монокультурною, а також демократичний напрямок розвитку ї̈ мовної політики. Визначено, що індикатором політичних мереж моделі є українська мова як державна інституція, а також інші політичні інституції, які регулюють мовну політику, визначають їі вектор розвитку та розв'язують мовно-політичні проблеми. У цьому сенсі виявлено, що напруження виникає унаслідок конкуренції двох основних політичних інститутів та ̈і ідеологій - національно-демократичної та комуністичної, які провокують протистояння, приміром, у ділянках українського і російського націоналізмізмів. 3’ясовано, що модернізація

(C) Савойська С. В., 2021 